\title{
A REGIONÁLIS TUDOMÁNY HELYZETE ${ }^{1}$
}

\author{
(The regional science - it's place among the regional sciences) \\ RECHNITZER JÁNOS
}

\section{A regionális tudomány aktualitása}

Az új tudományterületek születése és ezzel együtt intézményesülése mindig hosszú és nem egyszerủ folyamat. Az anya-diszciplínák nem, vagy csak nehezen fogadják el, hogy gyermekük felnőtt, önálló életet kíván élni. Viszont az egyre több mozgásteret és ezzel együtt intézményesített formát követelỏ új tudományterületek bizonyos idő után kikényszerítik az elszakadást, a saját elméleti és módszertani bázis kialakításával együtt az autonóm intézményi rendszerek létrehozását.

Ebbe a stádiumba került Magyarországon a kilencvenes évekre a regionális tudomány is. A regionális tudomány a társadalom, a gazdaság fejlődési folyamatainak térbeli, területi összefüggéseit, meghatározottságait vizsgálja önálló elméleti alapon és módszerekkel. A kulcskérdés a társadalmi mozgások térbeli dimenziója, mely azok megjelenési formáját, érvényesülését erősen befolyásolja.

A regionális tudomány tőbbségében a társadalomtudományokban alkalmazott eljárásokra építi kutatási módszertanát, de a térbeli viszonylatok miatt számos természettudományi kőzelítést, törvényszerüséget, analógiát, sôt szemléletmódot is használ vizsgálati szempontjai kőzött. A sokoldalú közelítési módok mellett további jellemzóje a regionális tudománynak, hogy a térben zajló társadalmi, gazdasági folyamatokat megpróbálja komplexen kezelni, keresve azok földrajzi meghatározóin túl a közgazdasági, szociológiai, politikai, történeti, de müszaki, urbanisztikai, környezeti elemeit is, s ezek együtteséböl következtet a jelenségek és a folyamatok alakulására, azok változására, törvényszerüségeikre. Kutatásaink során éppen arra keresünk választ, hogy a társadalmi, gazdasági jelenségek milyen sajátosságokat mutatnak a különféle térbeli dimenziókban, miként határozzák meg a térbeli viszonyok ezen tényezók szerkezetét, szereplöit, miként hatnak azok viselkedésére, akcióira. Azt elemezzük, hogy a gazdaság felszereltsége, a társadalom aktivitása és mindezek területi sajátosságai között milyen összefüggések mutathatók ki, illetve a területi egységek múszaki felszereltsége, ellátottsága mennyiben befolyásolja, erősíti vagy gyengíti a gazdaság fejlődését, átalakulását, modernizációját.

Napjainkban figyelmünk már egyre határozott arra irányul, hogy egy-egy térség, területi adottságait, természeti-környezeti-emberi-gazdasági-társadalmi-intézményi erőforrásait, mint endogén adottságokat miként lehet a fejlesztés, a megújítás motorjának tekinteni, miként erősödhetnek és válhatnak ezek a sajátosságok, a területi jellegből következő egyediségek, másságok a megújítás hordozóivá, s egyben meghatározóivá.

Alap-diszciplínának a földrajztudományt tekintjük, azon belül is a gazdaság- és társadalomföldrajzot. Mindezek közelítéseiben azonban nagyon határozottan teret nyert a 
közgazdaságtudomány, a szociológia, az államtudományok, az utóbbi évtizedekben a politológia és természetes szövetségesként folyamatosan érvényesül a történettudomány hatása. A másik oldalról a müszaki tudományok formálták a regionális tudományt, hiszen az épitészet, az urbanisztika, de az infrastrukturális rendszerrel foglalkozó diszciplínák (pl. a közlekedéstudomány) is erösen befolyásolták az elméleti alapok és módszerek alakulását, míg az elmúlt évtizedekben éppen a környezettudományi eredmények azok, amelyek nélkül ma már nem lehet igényes területi kutatásokat folytatni.

Napjainkban hazánkban a regionális tudomány fel- és újraértékelésének vagyunk tanúi. Ez arra vezethetö vissza, hogy a társadalom és gazdaság centralizált irányítási rendszere megszünt, helyette egyre jobban elötérbe kerül a decentralizáció, az önállóság, az egyéni és csoportos akaratok érvényesülése.

$\mathrm{Az}$ alábbiakban kiemelünk néhány tényezöt, amelyek a regionális tudomány elöretörését okozzák:

- a gazdasági és társadalmi decentralizáció hatására egyre több szereplö és intézmény jelenik meg, ezek már területi dimenzióban is gondolkodnak, sőt cselekvéseiknél azt is érvényesítik,

- az átmenet és az átalakulás felerösitette a korábban is meglévő területi különbségeket, amelyek megoldására választ kell adni, ki kell dolgozni a kezelés technikáit és módozatait,

- az európai integrációs folyamatok szinte kikényszerítik a regionális struktúrák értelmezését, az abban való gazdasági és társadalmi gondolkodás, tervezés, cselekvés intézményrendszereinek fokozatos kialakítását és müködtetését,

- a klasszikus gazdasági fejlesztési források már közel két évtizede kimerültek, most alakulnak ki a feltételei annak, hogy a térségekben, településekben, s azok adottságaiban lévő új erőforrásokat megismerjük és azokat a piacgazdaság eszközeivel feltárjuk, aktivizáljuk,

- az ủj infrastrukturális rendszerek kiépülésével megváltoznak a térségek kapcsolatai, funkciói, azok fejlődési, fejlesztési lehetöségeinél a korábbiaktól alapvetően eltérö kihívásokkal kell számolnunk,

- az önkormányzati rendszer bevezetésével alapvetöen megváltozott a települések és a térségek irányitásának rendszere, a helyi társadalom akcióterei kibővülttek, ưj, eddig nem ismert lehetöségek jelentkeztek a területi, a települési együttmüködésekben, kapcsolatokban, funkciókban,

- a centralizált, s egyben uniformizált társadalom és gazdaságirányítás megszủnésével lassan új gondolkodás és cselekvési módok jelennek meg a település- és területfejlesztésben, amelyekben a müszaki és fizikai rendezés a fejlesztési stratégiákra, a települések és térségek jövöbeli pályájának kijelölésére támaszkodva folyik és ezen integrált szemlélet válik a tervezés, a megvalósítás alapjává.

A vázlatosan felsoroltak is jelzik, hogy a regionális tudomány jelentös kihívások elótt áll. Az új szereplóket és azok igényeit, nemcsak elméleti rendszereinek dinamikus fejlesztésével, módszertani bázisának hathatós megalapozásával kell szolgálnia, hanem mindehhez intézményrendszereinek átalakitására és korszerüsítésére is szükség van.

A hazai regionális tudomány megteremtése hosszú időt vett igénybe, hiszen a hatvanas évek végétöl - a centralizált gazdasági irányítás szünésével - a hasznossága, a fontossága egyre nagyobb politikai elismerést nyert és az Akadémián belül is ezekben az években erősödött a felismerés az interdiszciplináris probléma-területek befogadása iránt. Erdei 
Ferenc vezetésével az évtized végétől müködött egy elnöki Területfejlesztési Bizottság, amely azzal is ösztönözte a területi kutatásokat, hogy részt vett a pécsi székhelyü Dunántúli Tudományos Intézetnek, mint a hazai területfejlesztési alapkutatásokkal foglalkozó akadémiai intézet új kutatási profiljának a kidolgozásában (1972, intézetigazgató Bihari Ottó akadémikus), ezután az Elnöki Bizottság megszủnt. A hatvanas évek közepétől (1966) a magyar kutatók bekapcsolódtak a Regional Science Association nevü nemzetközi tudományos szervezetbe, annak magyar tagozatának létrehozásával (első elnöke Kádas Kálmán). A nemzetközi programokban rendszeresen részt vettek és Budapesten az RSA eddig három európai konferenciát rendezett (1976, 1980 és 1985, a társaság fennállásnak 25. évfordulójának jubileumi konferenciajját is). A hetvenes évek vége és a nyolcvanas évek elején egyre nagyobb már az igény a területi kutatások iránt, aminek a megalapozásában az intenzív nemzetközi kapcsolatok is segítettek. Az Akadémia 1984-ban a korábbi bázisintézetre építve létrehozza a Regionális Kutatások Központját, mint a hazai regionális kutatások országos hálózatát, hiszen az intézetnek egységei voltak az alakuláskor a székhely Pécsen kívül Kecskeméten, Békéscsabán és Budapesten. A megerősödött intézeti háttér és a tudományterület egyre látványosabb fejlödése eredményeként 1986 ôszén megalakult a IX. és a X. Osztály közös új tudományközi bizottsága az MTA Regionális Tudományos Bizottsága 20 taggal (elnök Enyedi György az MTA r. tagja).

A regionális tudomány - még, ha azt korábban nem is így nevezték; területfejlesztési kutatások - tehát hatvanas évektöl intézményesen jelen van a hazai tudományos életben. Változó intenzitással és sikerrel folytak kísérletek a tudományterület önállósodására, mindezek, valamint a napjainkra megváltozott körülmények és igények lehetővé teszik, hogy a regionális tudomány mint önálló diszciplína elfogadottá és elismertté váljon.

\section{Kapcsolódás a nemzetközi trendekhez}

A területiség a társadalmi, gazdasági és politikai decentralizáció erōsödésével egyre nagyobb jelentóségre tesz szert. Mindez tükröződik a regionális tudomány terjedésében is, hiszen napjainkra már több mint 1200 egyetemi tanszék múködik a világban - ennek többsége Észak-Amerikában és Európában -, ahol oktatják és kutatják a térben zajló társadalmi és gazdasági folyamatok jellemzóit, törvényszerüségeit.

A regionális tudomány nemzetközi fejlödésében több trend ismerhető fel, azok adaptációja a hazai szakmai körökben viszonylag gyorsan kimutatható.

A módszertani és koncepcionális irányzatok azonban attól is függenek, hogy milyen jellegủek a tanulmányozott magyarországi térfolyamatok. A fejlett ipari országokban az 1970-es években bekövetkezett gazdasági szerkezeti, szervezeti és technológiai átalakulás, a világgazdasági korszakváltás új térfolyamatokat (pl. nemzetek közötti regionális integrációt) hozott létre - ám ezek a jelenségek a poszt-szocialista Közép-Európában csak napjainkban terjednek el. Ilyen értelemben az 1970-es évek nyugat-európai problémáival nézünk szembe, így a regionális tudomány tervezési és politikai alkalmazásában elmaradásunk nagyobb, mint az elmélet és módszertan terén. 
A regionális tudományos kutatások fő nemzetközi trendjét az alábbiakban foglalhatjuk össze:

- Az egyik irányzat az országok, országcsoportok - tehát a világgazdaság nagytérségei regionális folyamatainak elemzése, azok sajátosságainak összehasonlítása, a közös törvényszerűségek felvázolása. Ezek a kutatások például a Csendes-óceán térségének fejlődési problémáit éppen úgy boncolgatják, mint az Európai Unió regionális folyamatait.

Ebben az irányzatban a hazai regionális tudomány fö feladata a kelet-közép-európai országok átmenete és átalakulása regionális folyamatainak elemezése, kimutatva azokat a sajátosságokat, amelyek talán egyedülállóan a kilencvenes években zajlanak ezekben az országokban. A multiregionális együttélések és együttmüködések hazai elemzése azért is fontos, mert egyre nagyobb igény mutatkozik az országhatárok menti, sőt azoknál nagyobb térségekben megindult vagy éledező gazdasági-társadalmi kapcsolatok vizsgálatára, azok jellemzöinek (pl. együttmüködés intézményrendszerei) kidolgozására. (Gondolunk itt a Bécs-Pozsony-(Győr)-Budapest új fejlődési zónára vagy a Kárpátok-Tisza Eurorégió nyújtotta problémák elemzésére.)

A nemzetközi trendek másik metszete a lokális-regionális szint szerepének, mozgásterének felértékelödése a társadalmi irányításban, annak intézményrendszerében, s az új kapcsolódási rendszerek a központi kormányzatokkal, az állammal. Eme irányzathoz kapcsolódnak a különféle szemléletmódban megfogalmazott regionális politikák.

A hazai regionális tudományban lassan általánossá vált az a nézet, hogy az egyes térségek fejlesztésének a helyi adottságokra, endogén forrásokra kell épülnie. Mindezek csak akkor müködnek érdemlegesen, ha a fejlesztési döntésekben egyre jobban érvényesülnek a térségi szereplök akarata, $\mathrm{s}$ azok minél szélesebb körben decentralizálásra kerülnek. A hazai intézményi hagyományok, a politikai kultúra, a regionális szint értelmezése körül kialakult megosztottság és számos - föleg gazdasági - megfontolás csak nagyon óvatosan, váltakozó ritmusban engedi és fogja vissza a regionális dimenzió érvennyesítését a társadalom és a gazdaság fejlesztési és múködtetési rendszereiben. Egyértelmüen látni kell azonban, hogy az EU integrációs igényekkel párhuzamosan ki kell alakítani a regionális szint új, kimondottan decentralizáción alapuló rendszereit. Ehhez a hazai regionális tudomány nemcsak számos információt, szakmai segítséget tud nyújtani, hanem képes a nemzetközi kutatási eredmények alapján olyan megoldásokat is javasolni, amelyek az EU intézményeivel való együttmüködést eredményesebbé tehetik.

A nemzetközi regionális tudomány fejlödésében felismerhető irányzat, hogy az erösen gazdasági orientációjú - így a regionális gazdaságtanhoz kapcsolódó - kutatások mellett egyre nagyobb szerepet kapnak a társadalmi és ökológiai feltételek elemzései, azok együttes hatásrendszereinek értékelése.

A hazai regionális tudomány éppen a nagy tömegben jelentkező - kimondottan fejlesztés orientált - gyakorlati igények kielégítése mellett csak felszínesen kezeli vagy igencsak elhanyagolja a területi társadalmi struktúrák elemzését, azok változási irányainak regisztrálását, az ebből következö igények és szükségletek térbeli átrendezödését. Hasonlóan csak érintőlegesen bukkanunk olyan regionális kutatásokra, ahol a környezeti hatások átfogó rendszerei jelennek meg vagy éppen az ökológiai dimenziók állnak a fejlesztések középpontjában. Ennek a két új terưleti meghatározónak az elhanyagolása csökkentheti a regionális tudomány interdiszciplináris jellegét, de annak alkalmazhatóságát is jelentősen mérsékelheti.

Végezetül gyenge a hazai regionális tudomány módszertani bázisa. A leíró jellegủ elemzések kerültek túlsúlyba, hiányoznak a modellek, a különféle egzakt módszereknek 
alkalmazása. Nemzetközi trend, hogy a modellezés, a matematika rendszerek alkalmazása mellett vagy azokkal párhuzamosan széleskörủ grafikai információs rendszerek tủnnek fel az elemzésekben, amik jobban közelítik a térbeli jelenségek összetettségét, sajátosságait. Célszerú tehát a módszertani bázisokat erősíteni, ezek új szoftver rendszereinek terjesztésével és hardver állományainak megújításával.

\section{Intézményi bázis és a kutatási források}

A tudományterület bázisintézménye az 1984-ben alakult MTA Regionális Kutatások Központja ${ }^{2}$. Az Intézet nevéhez és kutatási témájához méltóan regionális, hiszen központja Pécsett található és az ország kilenc városában ${ }^{3}$ múködtet kisebb-nagyobb egységet, a kutatócsoporttól, a tudományos osztályon át egészen az intézetig. A kutatási témák kimondottan interdiszciplinárisak, hiszen a posztszocialista Kelet-Közép-Európa új regionális és urbanizációs folyamataitól kezdve az európai integrációs lehetőségeken vagy az önkormányzati rendszer kutatásán át, egészen a regionális tudomány és gazdaságtan alapkérdéseinek vizsgálatáig terjed, s mindezek folyamatosan bövülnek pl. a hátrányos helyzetủ térségek megújítási programjainak kidolgozásáig vagy az innovációk térbeli terjedésének elemzéséig. Az lntézetben 53 kutató dolgózik (1994), ebből egy fö az MTA tagja, három fö az MTA doktora, 27 fő a tudomány kandidátusa és jelenleg 8 tudományos cselekmény (kandidátusi értekezés) áll védés alatt, a minősítettek aránya 58,5\%.

$\mathrm{Az}$ Intézetben folytatott tudományos kutatások egy jelentős része közvetlenül alkalmazott kutatás, így azok eredményeit a központi kormányzati szervek éppen úgy felhasználják, mint a területi és helyi önkormányzatok, de egyre nagyobb a regionális kutatások iránt az érdeklódés a különféle gazdasági szervezetekben is ( $\mathrm{pl}$. bankok, biztosító társaságok, telefontársaságok). Az Intézet és önállóan gazdálkodó szervezeti egységei lényegében ezekből az alkalmazott kutatási megbízásokból tudják biztosítani a mủködésükhöz szükséges anyagi forrásokat, hiszen a költségvetési támogatások aránya az összes bevételen belül $40 \%$ körül van. Az intézet kutatói számos OTKA témát mủvelnek (25 elnyert pályázat 1994), de más hazai (OKTK, KMÜFA stb.), nemzetközi (PHARE stb.) és különféle egyéb forrásból (SOROS Alapítvány, SASAKAWA Alapítvány stb.) is elnyertek kutatási programokhoz támogatásokat. Az Intézet nemzetközi kapcsolatai kiterjedtek, ezek közös tudományos kutatásokban éppen úgy megjelennek, mint a nemzetközi szervezetekben való részvételben; elnökségi tagságtól a folyóiratok szerkesztő bizottságaiig.

Az Intézet anyagi támogatásával jelenik meg a regionális tudomány egyetlen elméleti folyóirata a Tér és Társadalom. Évente átlagosan 8-10 könyvet adnak ki, ezek részben egy-egy kutatási programra épülnek, részben konferenciák, tanácskozások közleményei, s az utóbbi 2-3 esztendőben több elméleti kötettel is gyarapították a regionális tudomány amúgy sem gazdag alapirodalmi bázisát. Az Intézet kutatói évente átlagosan 3-5 tudományos közleményt jelentetnek meg.

Fontos annak regisztrálása is, hogy az Intézet és szervezeti egységei nagy jelentőséget tulajdonítanak a regionális tudomány oktatásának. Így lényegében minden egységben a helybeli vagy a közelben található felsőoktatási intézményben a kutatók valamilyen formában (közös tanszék mủködtetése, tanszékek müködésében való részvétel, óraadás; graduális és posztgraduális képzési programok szervezése) oktatási tevékenységet folytatnak, s ezzel a regionális tudomány terjesztését szolgálják. Ennek a széleskörú 
oktatási részvételnek is köszönhetö, hogy az Intézet éppen a felsőoktatási intézményekkel közősen több elméleti jellegủ könyvet jelentet meg ${ }^{4}$.

Az MTA RKK-n kívül elsősorban az MTA Földrajztudományi Kutatóintézetben és a tudományegyetemek gazdaság- és társadalomföldrajz tanszékein folynak a regionális tudományhoz kapcsolódó kutatások. Sajnos, a Budapesti Közgazdaságtudományi Egyetem nem tölti be azt a fontos szerepet, melyet a közgazdasági felsőfokú iskolák világszerte játszanak a regionális tudomány formálásában.

Az MTA mindegyik területi bizottságában müködik területi kérdésekkel foglalkozó szakmai csoport, amely az adott régió szakember állományát összefogja, illetve fórumot nyújt a szakmai ismeretek átadására.

Kimondottan a regionális tudományt megcélzó tudományos pályázat nincs. Az OTKA téma felsorolásai között szerepel a regionális tudomány (2048) címszó, azonban a pályázatok rendszeresen a földrajzi, meteorológiai és geofizikai témákkal együtt kerülnek az élettelen természettudományok egyik szakbizottságában elbírálásra ${ }^{5}$. Az OKTK témák között a területfejlesztés megalapozását szolgáló blokk ${ }^{6}$ lehetöséget kínálhat a regionális tudomány egyes kérdéseinek múveléséhez, amennyiben ezek az egyes minisztérium aktuális érdeklődésének megfelelnek. Léteznek kutatási alapítványi programok és egyéb gazdaságfejlesztési alapok, non-profit szervezetek, ahol szintén lehetőség kínálkozik kisebb kutatási támogatás megszerzésére (OFA, MVA).

\section{A regionális tudomány szürkeállománya}

A regionális tudományt mủvelók körét nem könnyủ meghatározni. Induljunk ki abból, hogy napjainkban hány fö alkothatja a tudományterület minösitett szakmai bázisát.

Ennek egyetlen autentikus forrása az MTA nem akadémikus köztestületi tagjainak jegyzéke (1994. okt.). Ebben a X. Földtudományok Osztályához sorolt Regionális Tudományos Bizottsághoz 14 fö kérte magát regisztráltatni, ebböl három MTA doktora (egy közgazdaságtudomány, kettỏ földrajztudomány) és 11 a tudomány kandidátusa (közgazdaság-tudomány 3 fö, földrajztudomány 8 fö). Ismereteink szerint éppen a Regionális Tudományos Bizottság tagjai közül is többen még nem regisztráltatták magukat az MTA Köztestületében, illetve a nevezett forrás megjelenése óta új tudományos fokozatok is születtek ehhez a szakterülethez kapcsolódva. A Bizottság - az 1996. évi tisztújítást követően - a IX. (Gazdaság- és Jogtudomány) Osztályhoz kíván csatlakozni.

Összességében azt állapíthatjuk meg, hogy becslésünk szerint napjainkra 25 és 30 fỏ kőzé tehetjük azon minösítettek számát akik a Regionális Tudományos Bizottsághoz kapcsolódnak, ezek között egy fó az MTA rendes tagja, a doktorok száma 3-5 fó, míg a többiek 22-25 fö a tudomány kandidátusai. (Ezt a közelítést hivatott alátámasztani, hogy az 1993. évben rendezett bizottsági tisztségviselöi választáson a meghívott 68 fö közül 32 fö jelent meg és a bizottság 14 tagját megválasztotta.)

Regionális tudományos képzés jelenleg van kialakulóban. A hetvenes évek elején még volt a Közgazdaságtudományi Egyetemen olyan szak, ami a területfejlesztéshez kapcsolódott, ám a nyolcvanas évek elejére ez a specializáció megszünt. Az alapdiszciplinákban, így a közgazdaságtanban, a geográfiában, a szociológiában, az állam- és jogtudományban, valamint a müszaki tudományokon belül az építészetben, az infrastrukturális rendszerekhez kapcsolódó mérnőki tudományokban szerzett egyetemi képzéssel rendelkeznek a tudományterület hazai mủvelöi. A kiegészitó, posztgraduális 
képzés müködik a Janus Pannonius Tudományegyetem Közgazdaságtudományi Karán és az ELTE Szociológiai Intézete által szervezett négy vagy hat féléves kurzusokon ${ }^{8}$. Nem fó szakként, hanem kiegészítő másodszakként, szakirányként a regionális tudomány különféle közelítése az egyetemi graduális oktatásban megjelenik (Janus Pannonius Tudományegyetem Közgazdaságtudományi Karán területfejlesztési szakirány az MTA RKK Dunántúli Tudományos Intézetének részvételével, ELTE, JPTE, JATE, KLTE geográfus képzés településfejlesztési szakirány). A föiskolák közül a Széchenyi István Főiskola Közgazdasági Fakultásán öt éve múködik a Településgazdász szakirány, ahol a regionális tudomány gyakorlati alkalmazását oktatják az MTA RKK és a föiskola által alapított közös - Nyugat-magyarországi Tudományos Intézetére épülő - tanszék irányításával. Egyre több egyetem és fơiskola különféle, inkább a társadalomtudományokhoz, de a mérnöki tudományokhoz is kapcsolódó fakultásain jelennek meg olyan tantárgyak (pl. regionális gazdaságtan, területfejlesztés, regionális politika), amelyek a regionális tudományok egyes elemeit, fontosabb részterületeit oktatják ${ }^{9}$. Az év végére készul el a KTM megbízása alapján egy felmérés a területfejlesztéshez kötődő szakmai képzésekröl, ennek ismeretében talán több áttekintésünk lesz a tudományterület oktatásáról.

A regionális tudományt mủvelő első doktori program 1995-ben indult el a pécsi Janus Pannonius Tudományegyetem Közgazdaságtudományi Karán, amelyhez egy TEMPUS ${ }^{10}$ program is kapcsolódik.

A kutatói és oktatói kapacitáson kívül szólni kell arról, hogy a regionális tudomány gyakorlati müvelőinek száma érzékelhetően növekedett a kilencvenes évek elejétől. A területi és helyi önkormányzatok, a különféle decentralizált kormányzati szervek, a térségek, települések fejlesztésével foglalkozó vállalkozások, intézmények, különféle honprofit szervezetek egyre nagyobb számban alkalmaznak olyan szakembereket, akik érdeklődnek a területi folyamatok iránt. Vélhetően a társadalmi decentralizáció növekedésével a gyakorlati szakemberek száma is emelkedik, így a tudományterület iránti érdeklődés, kutatási eredményeink iránti szükséglet fokozódásával is számolhatunk.

\section{Tudományos publikációk}

A regionális tudomány hazai folyóirata az 1987-től megjelenó Tér és Társadalom, amit az MTA Regionális Kutatások Központja ad ki intézeti finanszírozásban. A folyóirat évente négy számot jelentet meg, így összességében 20-25 tanulmánynak, illetve további 10-15 közleménynek nyújt megjelenési lehetóséget. Az MTA RKK jelentős anyagi áldozatokat vállal a Tér és Társadalom fennmaradásáért, sajnos akadémiai támogatást eddig nem kapott a folyóiratra, igy nem állithatjuk, hogy az hosszú távon is életben tartható.

Több társadalomtudományi folyóirat közöl a regionális tudományhoz kapcsolódó cikkeket $^{\prime \prime}$, azonban ezek többségében nem elméleti jellegü tanulmányok, hanem a hazai vagy nemzetközi területi folyamatok áttekintése, azok egy-egy aktuális metszetének (önkormányzati rendszer, településhálózat, térségi válságok, regionális politika stb.) bemutatása, értékelése. Nem mondhatjuk azt, hogy a területi kérdésekkel foglalkozó témák iránt nem érdeklödnek a különféle folyóiratok, a jó színvonalú tanulmányoknak nincs publikációs nehézsége. 
A regionális tudomány hazai müvelését, mind a kutatásban, mind az oktatásban nagyban gátolja, hogy magyar nyelven elméleti megalapozó munka nagyon kis számban található. A szakmai körök nem kezdeményezték eddig a jelentősebb külföldi szakma alakító müvek leforditását, nincsenek rendszerező jellegü kézikönyvek, módszertani kiadványok. Ezek hiányában a tudományterület ismereteinek terjesztése, annak különösen az oktatásban való elterjesztése jelentős akadályokba ütközik. A kilencvenes évek elejétöl éppen az MTA RKK-hoz tartozó kutatói bázis közremüködésével már több elméleti és rendszerezö könyv, tanulmánykötet jelent meg, azonban ezek sem tudják pótolni azt a hiányt, ami a tudományterület mélyebb szakmai megalapozását, s egyben - éppen a társadalmi igények változása miatti - intenzívebb terjesztését szolgálná.

A szakma nemzetközi kapcsolatai részben intézményesek, részben pedig a kutatókhoz kötődnek. A regionális tudomány nemzetközi szervezetének - a Regional Science Association - magyar tagozatában 20-30 fö között van a regisztrált tagok száma, az éves európai közgyülésen 3-5 magyar elöadás is elhangzik, így a képviseletünk biztositott a nemzetközi szervezetben.

Az RSA Végrehajtó Bizottságának magyar tagja is volt 1990-1994 között, ám az RSA magyar tagozatának hazai müködése nem kielégitö.

Több nemzetközi folyóirat szerkesztő bizottságában képviseltetjük magunkat, magyar szerzöktöl rendszeresen jelennek meg ezekben közlemények.

Becslésünk szerint évente 10-15 nemzetközi konferencián részt vesznek a regionális tudománnyal foglalkozó szakemberek, ezek között hazai rendezésben 2-3 esettel találkozunk évente. Örvendetes, hogy egyre több, föleg EU támogatással induló kutatási program jelent meg a szakmában, de két- és háromoldalú együttmüködések is vannak a regionális folyamatok elemzésére, értékelésére.

A regionális tudománnyal foglalkozó szakemberek szakmai kommunikációját szolgálja a Bizottság által rendezett konferenciák ${ }^{12}$, illetve a különféle hazai területfejlesztéssel kapcsolatos tanácskozásokon való részvétel.

\section{Tudományos infrastruktúra}

A tudományterület infrastrukturális bázisa két csomópontra épül, az első a könyvtár és információs szolgáltatás, a másik a kutatást segítő számítógépes rendszerek.

A könyvtár és információs szolgáltatás bázisát az MTA RKK Központi Könyvtára jelenti. A könyvállomány közel 30 ezer kötet, ennek megközelítöleg $80 \%$-a kapcsolódik a regionális tudományhoz, 54 külföldi folyóirat egység, 120 belföldi folyóirat egység jár rendszeresen a könyvtárba. A könyv és folyóirat állománnyal jól ellátott könyvtárban gondot jelent, hogy a különféle kutatási dokumentumok más intézményektöl csak részben érkeznek be, így nem tudják teljes mértékben áttekinteni a kutatási témákat, azok eredményeit.

A tudományterületen nincs regisztráció arról, hogy milyen kutatási témákat, mely intézményekben folytatnak. Célszerü lenne legalább kétévente áttekinteni a kutatási témákat, azok dokumentumait begyüjteni és rendszerezni, illetve mindezekről kiadványt megjelentetni.

A regionális tudomány mủvelésének alapja, hogy területi szintü adatbázisok álljanak rendelkezésre. A hazai területi statisztikai adatrendszer még nem volt képes igazodni a megváltozott igényekhez, illetve számos ủj szereplö jelent meg, akik értékelhető területi 
\$zintü adattal rendelkeznek. Nincs rendszerezett és nyilvántartott adatbázis a területi elemzésekhez, azok rendkívül szórtan, esetlegesen érhetők el, a rendszerezettségük kimondottan gyenge, gépi feldolgozottságukban hatalmas különbségek vannak. Mindezek mellett módszertani hiányosságokkal is találkozunk, hiszen például nem megoldott a területi jövedelem számítás kérdése, így a nemzetközi összehasonlítások nehézkesek stb. A tudományterületnek nagy eröket kell megmozgatni az információs renđszer áttekintésére, annak rendszerezésére, a kapcsolódási pontok egyértelmü felvázolására és az elemzések módszertani kérdéseinek tisztázására.

A kutatást segítỏ számítógépes rendszerek egyre természetesebb tényezői lesznek a regionális tudománynak. Több kutatóhely bekapcsolódott a hazai és nemzetközi adatátviteli rendszerekbe, elterjedtek olyan szoftverek, amelyek az adatbázisok térképi ábrázolását megkönnyítik vagy az elemzéseket segítik.

\section{A tudományterület teljesitményének értékelése}

A regionális tudomány hazai eredményei lényegében a kilencvenes évektől jelentkeznek. Az alapkutatások jól átfordíthatók a gyakorlati alkalmazásba, hiszen ugrásszerüen megnőtt az igény a területi folyamatok áttekintésére, értékelésére. A hazai regionális tudomány mủvelöi, akik különféle alap-diszciplinákban szerezték képzettségüket, éppen a területi szemlélet érvényesítésével képesek voltak a jelentkező igényekre reagálni, s vizsgálataikkal a nemzetközi szakmai színvonalhoz igazodni.

A regionális tudomány kutatási eredményei széles skálát fognak át: a nemzeti területfejlesztési koncepció megalapozása, a területfejlesztési törvény-elökészítése, Budapest szerepének, helyének áttekintése az európai városrendszerekben, az ország térszerkezetének bemutatása a rendszerváltozás hatására, az innovációk területi terjedésének jellemzői, az őnkormányzati rendszer egészének és egyes részeinek (gazdálkodás, szervezet, közigazgatási szerkezet) megújítása, az európai regionális politika alkalmazhatóságának vizsgálata, az Alföld nagyrégió, vagy a Dél-Dunántúl térségének fejlesztési koncepciójának kidolgozása, a különféle ágazati fejlesztési irányok területi metszeteinek összeállítása (ipar, távközlés) és a különféle új gazdasági tevékenységek telepítési tényezöinek értékelése (bankok, biztosítási intézmények, modern üzleti szolgáltatások), s végül a határ menti együttmúködések tereinek felvázolása, azok különféle hatásainak értékelése.

A publikációkban és a kutatási programokban tehát megjelentek a tudományterület nemzetközi trendjei, ugyanakkor azokat éppen a magyar vagy pontosabban kelet-középeurópai sajátosságokkal gazdagitották. Ezen teljesítmények elismerése a nemzetközi konferenciáktól kezdve, a külfooldi folyóiratok szerkesztő bizottsági tagságán át, egészen az emelkedő számú nemzetközi kutatási programokig terjed.

Napjainkban több felsőoktatási intézmény felismerte, hogy a regionális tudomány egészének és egyes alkotó elemeinek integrálása az oktatási programokban szükséges, azok iránt a társadalmi érdeklöđés növekedett. İgy vélhetően komplex és részképzési programok is megindulhatnak, amik a szakember bázist bővítik, de közben a tudományterület ismertségét is fokozzák. A graduális képzések mellett már törekvések és kidolgozott kezdeményezések is vannak a tudományos képzés beindítására, ennek szakmai hátterét viszont döntỏen az akadémiai kutatóbázis nyủjthatja. A tudományterületen a nagyobb rendszerezó múvek még hiányoznak, ám több biztató jel sejteti, hogy két-három 
esztendỏn belül mérséklődnek a hiányosságok, megjelennek az átfogóbb jellegủ, $\mathrm{s}$ egyben a regionális tudomány elméleti megalapozását segítỏ könyvek, tanulmánykőtetek.

A regionális tudomány kapcsolata a gyakorlattal kimondottan erős. A kutatási megrendelések a különféle központi kormányzati szervektöl és területi-helyi önkormányzatoktól származnak, így egy folyamatos kölcsönkapcsolat figyelhetö meg az eredmények hasznosításában és a kutatási igények alakításában. A permanens kommunikáció a gyakorlattal persze negatívumokkal is jár; hiszen éppen a hiányolt elméleti munkáktól veszi el a kutatási kapacitásokat, viszont kínálja a szakmai ismeretek terjesztését, egy igényesebb regionális politika kidolgozásának szükségességét, ösztönzi az állandó szakmai jelenlétet. Valójában a tudományterület innovatív hatása is ebben a dialógusban határozható meg. Ennek terei napjainkra egyre bỏvülnek, hiszen a korábban említett szereplökön kívül már újabbak (gazdasági érdekképviseletek, gazdasági szereplők, nem kormányzati szervek stb.) is felismerik a területi folyamatokban rejlő lehetőségeket, azok megújit́́st segitó hatásait.

\section{Jegyzetek}

1 A tanulmány a Magyar Tudományos Akadémia IX. Osztálya felkérésére készült, s részét képzi a társadalomtudományokkal foglalkozó osztály jelentésnek.

${ }^{2}$ Az MTA társadalomtudományi kutatóhelyeinek 1994, évi tudományos tevékenysége. Szerk. Pritz P. Budapest, 1995.

${ }^{3}$ Dunántúli Tudományos Intézet Pécs; Alfoldi Tudományos Intézet Kecskemét, Békéscsaba, Szolnok, Debrecen; Nyugat-magyarországi Tudományos Intézet Győr, Szombathely, Észak-magyarországi Osztály Miskolc; Budapesti Osztály Budapest.

${ }^{4}$ Fejezetek a regionális gazdaságtan tanulmányozásához. Szerk. Rechnitzer J. MTA RKK Pécs-Györ, 1995.

${ }^{5}$ A mellékletben készítettünk egy ósszeállítást a regionális tudományhoz kapcsolódó, az OTKA-ból támogatott kutatásokról 1993-1997. között.

6 OKTK $\mathrm{H} / \mathrm{b}$. fơirány: A terület- és településfejlesztés társadalmi-gazdasági ósszefüggéseivel, valamint a környezetvédelemmel kapcsolatos kutatások.

${ }^{7} \mathrm{Az}$ új akadémiai ciklus tisztújítása elött, 1996. szeptember végéig 35 köztestületi tag regisztráltatta magát a Bizottságnál, amelynek újra választása megtörtént 1996. október végén. Az elnök a kơvetkezỏ három éves ciklusban Lackó László professzor lett.

${ }^{8}$ A Széchenyi István Föiskolán uzemgazdászok és mémőkők számára terveznek posztgraduális településgazdász képzést.

9 Godollooi Agrártudományi Egyetem, Miskolci Egyetem, Államigazgatási Főiskola, Bẻkéscsabai Tanárképző Föiskola.

${ }^{10}$ Regionális és európai szakemberek képzési programja, posztgraduális és doktori képzésre, a program tagjai a Párizs VIII. Egyetem, Leeds Egyetem, Barcelona Egyetem, JPTE-Pécs, SZIF-Györ, PATE Állattenyésztési Kara Kaposvár, Vegyipari Egyetem Veszprém.

${ }^{11}$ Gyakorlat orientált kezdeményezés volt a Falu Város Régió címú folyóirat a KTM kiadásában, amely inkább a fejlesztés rendszereivel foglalkozott, de sajnos a folyóirat kiadása szünetel. A Comitatus - a megyei önkormányzatok folyóirata - rendszeresen jelentet meg regionális tudományi szakcikkeket, ezek között több elméleti irás is helyet kapott.

12 Területi szemlélet a közgadaságtudományban, avagy van-e regionális gazdaságtan Magyarországon. Győr, 1990; Válságtérségek Magyarországon Budapest, 1991. ;A regionális tudományok integrálása a felsöoktatásba Győr, 1992.

\section{Válogatás a regionális tudományos publikációkból}

Barta Gy. (1994) Gondolatok a szocialista telephelyelmélet megfogalmazásához. Tér és Társadalom 3-4. Sz. 79 90. o.

Bartke I (1989) A társadalom és a gazdaság területi szerkezetének alapvonásai. Akadémiai Kiadó, Budapest. 
Bartke I. (1994) A teruleti (gazdasági) fejlödés társadalmi hajtóerỏi és az állami szabályozás. Tér és Társadalom 3-4. 1-22. 0 .

Bartke I. (1994) Néhány gondolat a regionális tudományról. Comitatus 4. sz. 40-44, o.

Csatári B. (1994) Az Alföld helyzete és perspektívái. Alföld kutatási program 1991-1994. Békéscsaba, Nagyalfold Alapitvány. 99 o.

Development strategies in the Alpine-Adriatic Region. Szerk. Horváth Gy. Pécs, Centre for Regional Studies, 1993. 3500.

Enyedi Gy. (1983) Földrajz és társadalom. Tanulmányok. Magvető, Budapest.

Enyedi Gy. (1988) A városnövekedés szakaszai., Akadémiai Kiadó, Budapest.

Enyedi Gy. (1990) New basis for regional and urban policies in East-Central Europe. Pécs, Centre for Regional Studies (Discussion papers 9.)

Enyedi Gy. (1992) Regionális fejlỏdés és kőrnyezetvédelem Magyarországon. Info-Társadalomtudomány, 21. Sz. 35-43, 0 .

Enyedi Gy. (1994) Teruletfejlesztés és regionális átalakulás a posztszocialista országokban. Társadalmi Szemle. 8-9. sz. 133-139. o.

Enyedi Gy. (1994) Területfejlesztés új feltételek között. Magyar Tudomány, 11, sz. 1322-1326. o.

Erdỏsi F. (1993) Az Alfold infrastruktúrájának jellemzỏi és fỏbb fejlesztési feladatai. Tér és Tårsadalom 3-4. sz. 3-34. 0 .

European challenges and Hungarian responses in regional policy. Szerk. Horváth Gy., Hajdú Z. Pécs, Centre for Regional Studies, 1994. 517 o.

Faragó L. (1994) Adalékok a teruletfejlesztéssel kapcsolatos fogalmak vitájához. Tér és Társadalom 3-4. sz. 2341. 0 .

Faragó L., Hrubi L., Horváth Gy. (1990) Szerkezetátalakítás és regionális politika. Budapest. TS $2 / 2$ Programiroda. 1530 .

Fejezetek a regionális gazdaságtan tanulmányozásához. Szerk. Rechnitzer J. Györ- Pécs, MTA RKK, 1995. 2520.

Horváth Gy. (1992) Az európai integráció és a magyar regionális politika. Gazdaság. kulönszám. 128-131. o.

Horváth Gy.(1992) A magyar regionális politika súlypontjai. Tér és Társadalom, 1-2. 1-15. o.

Hungary: Society, state, economy and regional structure in transition. Szerk. Hajdú Z. Pécs: Centre for Regional Studies, 1993. 293 o.

Kószegfalvy Gy. (1991) Települési infrastruktúra. (Területi és települési kutatások, 8.) Akadémiai Kiadó,. Budapest.

Lackó L. (1988) Területi fejlödés, politika, tervezés. Akadémia Kiadó, Budapest. 195. o.

Lackó L. (1994) A regionális tudomány magyarországi helyzetének néhány jellemzője. Comitatus 4. 44-49. o.

Lackó L. (1994) Regionális politika - irányitási modellek. Tér és Társadalom 3-4. sz. 41-47. o.

Magyarország falutípusai. Budapest. Szerk. Beluszky P., Sikos T. T. MTA Földrajztudományi Kutató Intézet (Elmélet-módszer-gyakorlat, 22.), 1982.

Matematikai és statisztikai módszerek alkalmazásának lehetőségei a területi kutatásokban. Szerk. Sikos T. T., Akadémiai Kiadó, Budapest.

Nemes Nagy J. (1987) A regionális gazdasági fejlődés összehasonlító vizsgálata.., Akadémiai Kiadó, Budapest.

Nemes Nagy J. (1993) Bevezetés a regionális tudományba. ELTE Szociológiai és Szociálpolitikai lntézet, Budapest.

Nemes Nagy J. (1994) A Dél-Dunántúl a piacgazdasági átmentben. Tér és Társadalom 1-2. sz. 25-37. 0.

A nyitott határ A gazdasági és szellemi erőforrások innovációorientált fejlesztése az osztrák-magyar határmenti régiókban. Szerk. Rechnitzer J. Györ, MTA RKK Észak-dunántúli Osztály, 1990. 196 o.

Rechnitzer J. (1993) Szétszakadás vagy felzárkózás? A térszerkezetet alakító innovációk. Pécs-Gyór, MTA RKK 2070.

Rechnitzer J. (1994) A helyét kereső regionális tudomány. Comitatus 8-9. sz. 35-38. o.

Regional policy and local governments. Szerk. Horváth Gy. Pécs, Centre for Regional Studies, 1991. 215 o.

Szirmai V. (1988) "Csináli városok". Magvető Kiadó, Budapest.

Társadalmi- területi egyenlõtlenségek Magyarországon. (Szerk. Enyedi Gy.) KJK, Budapest, 1993. 383. 0.

Telepulés, gazdaság, igazgatás a térben. Szerk. Kovács K. Pécs, MTA RKK, 1993. 327 o.

A regionális tudományok integrálása a felsỏoktatásba. Területi szemlélet a kőzgazdaságtudományban, avagy van-e regionális gazdaságtan Magyarországon? Szerk. Lados M., Kocsis Zs. Gyôr, MTA RKK, 1992. 209 o.

Tér-Idô-Társadalom. Huszonegy tanulmány Enyedi Györgynek. (Szerk. Tóth J.) MTA RKK Pécs, 1990. 